\begin{tabular}{c|c|c}
\hline \hline $\begin{array}{c}\text { Vol. 35(4):373-381 } \\
\text { http://dx.doi.org/10.4217/OPR.2013.35.4.373 }\end{array}$ & Ocean and Polar Research & December 2013 \\
\hline
\end{tabular}

\title{
Article
}

\author{
동아시아 국가들의 태평양 쟁탈전 : \\ 한국, 일본, 중국의 남태평양 도서국가 외교
}

\author{
박영준* \\ 국방대학교 안전보장대학원 군사전략학과 \\ (412-706) 경기도 고양시 덕양구 제2자유로 33
}

\section{Competitive Efforts Regarding the South Pacific Islands by South Korea, Japan and China}

\author{
Young-June Park \\ Department of Military Strategy, National Security College, Korea National Defense University \\ GoYang 412-706, Korea
}

\begin{abstract}
The Pacific Island Forum that consists of 14 island countries in the South Pacific has long been the focus of keen attention from East Asian countries such as South Korea, Japan and China. The South Pacific area was controlled by Japan right after the First World War. The League of Nations bestowed the right of trusteeship over the region to Japan, one of the victors in the war. However, the U.S. considered the area indispensible for its security interests in the Pacific after victory in the Second World War. With the end of Cold War period, the region again began to gain the competitive attention of Japan, China and Korea. Japan has made efforts to give economic assistance to this region by holding the Japan-Pacific Islands summit every three years. In addition, Japan is promoting a security engagement with this region by dispatching Self Defense Forces with the aim of initiating construction and development projects. In response to Japan's active involvement in the region, China also began to convene a summit meeting with these countries in 2006, making pledges of economic assistance. Furthermore, Chinese civilian companies struck deals of investment with municipal institutions in the region with a view to enhancing China's influence in the region. Japan's and China's active engagement in the region has galvanized South Korea to craft a more effective strategic approach to the region.
\end{abstract}

Key words : Pacific Island, South Korea, Japan, China, maritime policy

\section{1. 문제의 제기}

2012년 5월 27일, 일본의 아사히신문(朝日新聞)은 제 6회 일본-태평양 도서국 정상회의가 개최된다는 사실을 보도하면서, 태평양 도서국가들에 대해 일본 뿐만 아니 라, 중국, 미국, 러시아, 그리고 한국이 2010년대 이후

\footnotetext{
*Corresponding author. E-mail : yjpark607@daum.net
}

경쟁적으로 정상회담 및 각료회의를 개최하고 있는 사실 을 부연설명하면서, 바야흐로 “태평양 쟁탈전"의 양상이 전개되고 있다고 보도하였다. 같은 해 11월 13일, 중앙 일보는 한국 정부가 태평양상의 쿡 제도와 국교를 수립 할 것이라고 보도하면서, 남태평양의 도서국가들을 두고 미국과 중국이 사실상 패권경쟁을 벌이고 있다고 분석하 였다.

한국과 일본의 언론이 주목하고 있는 남태평양 도서국 
가들은 피지, 마샬군도, 마이크로네시아, 키리바시, 투발 루, 나우루, 바누아투, 솔로몬제도, 사모아, 통가, 니우에, 쿡 제도, 팔라우 등 남태평양 상에 떠 있는 14 개 정도의 섬나라들을 가리킨다. 쿡 제도의 경우 면적 236 평방킬로 미터, 인구는 2011년도 기준 1만 777명에 달하는 조그마 한 섬나라이고, 다른 나라들도 인구와 면적 기준으로 자그 마한 도서국가들이다. 경제적으로도 발달된 산업기술을 갖고 있지 않고, 시장 규모도 미약한 이들 도서 국가들에 대해서 동북아의 한국, 중국, 일본, 그리고 미국과 러시아 까지 가세해서, 경쟁적으로 협력관계를 강화하고, 영향력 을 확대하려는 요인들은 무엇일까?

본 소고는 크게 두 부분으로 구성된다. 전반부에서는 남태평양상의 도서국가들이 역사적으로 어떠한 전략적 중 요성을 갖고 왔는지를 제 1,2 차 세계대전시 일본과 미국 의 국방정책을 중심으로 설명할 것이다. 후반부에서는 20세기 후반에 유엔 해양법 협약 발효 전후를 중심으로 해서, 태평양 도서 국가들이 어떠한 전략적 중요성을 갖게 되었는지를 살펴보고, 이들 국가들에 대해 동북아 국가들 이 어떠한 외교공세를 전개하고 있는가를, 일본, 중국, 한 국의 순으로 각각 검토하도록 하겠다. 그리고 이를 바탕으 로 한국이 향후 남태평양 도서 국가들에 대해, 나아가서는 국제해양질서에 대해 어떤 전략기조를 갖고 정책을 전개 해야 하는가에 대한 정책제언을 제시하고자 한다.

\section{2. 남태평양 도서국가의 전략적 중요성: 태평양 전쟁 전후 일본과 미국}

제1차 세계대전 이후 일본 제국주의와 남태평양 도서국가 남태평양 도서 국가들이 국제정치의 장에서 주목을 받 게 된 것은 서구 국가들의 지리상의 발견, 특히 19 세기 중 엽 이후 영국, 프랑스, 독일 등이 세계적인 규모로 식민지 팽창을 하면서부터이다. 19세기 후반 이후 태평양상의 국 가들이 각기 후발 자본주의 국가인 미국과 독일에 의해 미서전쟁 등을 계기로 영유권이 결정되는 가운데, 비스마 르크 제도 등은 독일의 영유권이 된 바 있다.

그런데 1914년 8월에 발발한 제1차 세계대전은 남태평 양상의 도서 국가들의 명운을 다시 바꿔 놓는 계기가 되 었다. 제 1 차 세계대전이 발발하자, 유럽 방면에서 독일군 과 맞서 싸우던 영국은 1902년 이래 동맹관계를 맺어오던 일본에게 동아시아 및 태평양상의 독일 근거지들을 공격 해 달라는 요청을 전하였다. 이에 대해 1914년 당시 일본 은 독일령이었던 산동반도의 칭따오(靑島) 독일 해군기지 를 공략하고, 이어서 제국 해군 제 1 함대 남견(南遣) 지대 를 편성하여 남태평양상의 마리아나 및 마샬제도를 점령 하였다. 일본은 점령된 남태평양상의 도서 지역에 방비대 를 편성하여 1 차 세계대전 종료 시까지 군정을 실시하였 다(Eguchi 1992).

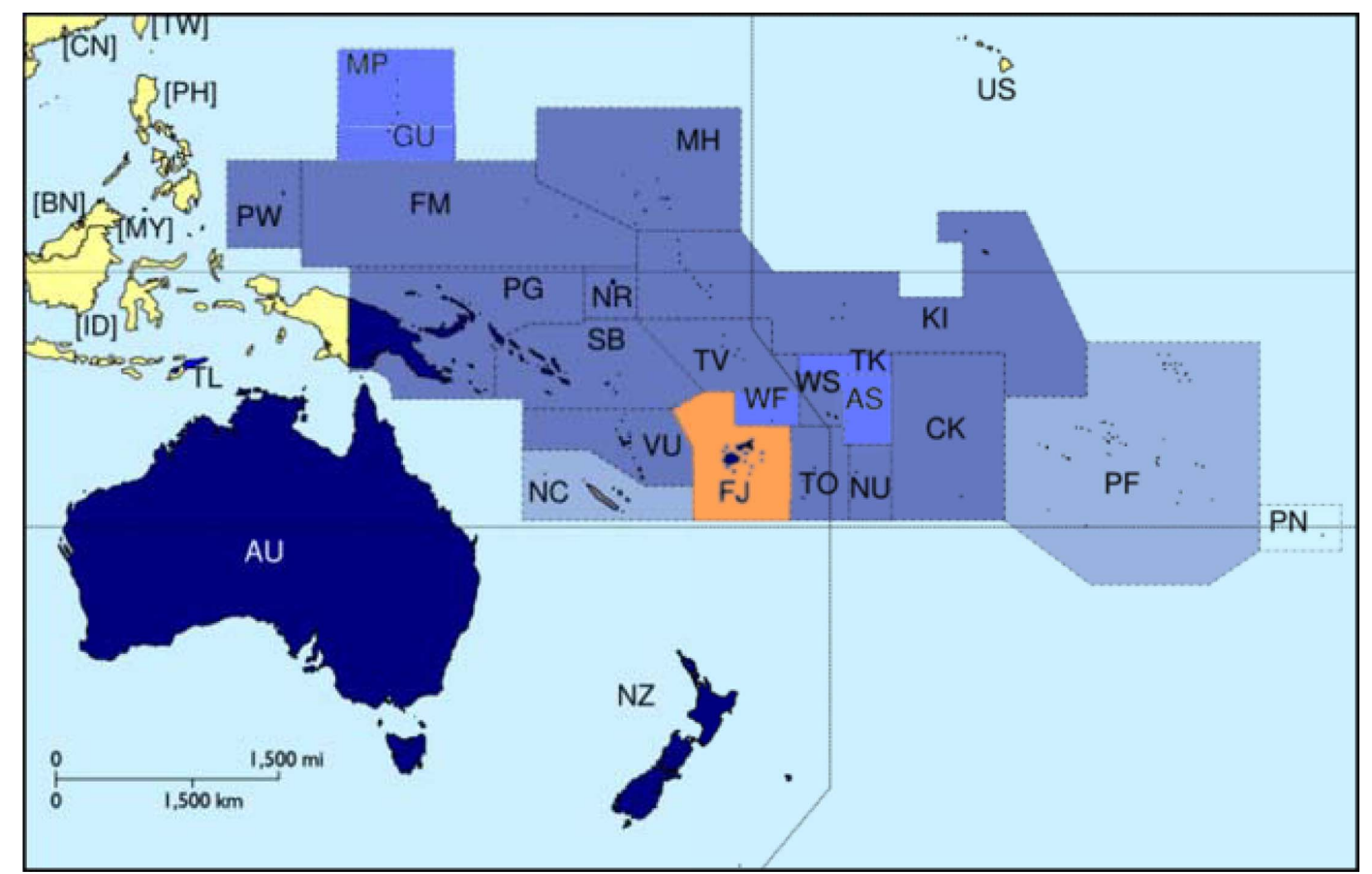

Fig. 1. South Pacific Islands (NU: Niue, CK: Cook Islands, FM: Micronesia, KI: Kiribati, NR: Nauru, WS: Samoa, PW: Palau, PG: Papua New Guinea, MH: Marshall Islands, VU: Vanuatu, SB: Solomon Islands, TO: Tonga, TV: Tuvalu) 
그런데 유럽 방면에서의 전역이 장기화되고, 독일의 무 제한 잠수함 작전에 의해 영국, 프랑스 등 연합국이 고전 을 치르게 되자, 영국은 1916년 12월, 재차 일본에 대해 해군 함대를 지중해 방면으로 파병해 줄 것을 요청하게 되었다. 처음에는 유럽 방면에의 병력 파견을 주저하던 일 본 가토 다카아키(加藤高明) 내각은 결국 1917년 2월, 전 후 남태평양 방면의 도서 영유를 조건으로 하여, 군함 1척 과 구축함 2 척의 파견을 승인하였고, 결국 총 17 척의 함정 을 지중해 방면으로 파견하게 되었다(Hirama 1998). 지중 해 방면에 파견된 일본 함대는, 3 척의 함선이 격침되거나 파손되는 피해를 입으며, 영국 해군이 수행하는 대독 잠수 함 작전을 지원하는 등의 전투 임무를 수행하였다. 그러다 가 결국 제 1 차 세계대전이 독일의 항복, 영국, 프랑스, 미 국 등의 연합국 승전으로 귀결되자, 일본도 승전국의 일원 이 되었고, 지중해 방면에 참전한 일본 해군은 영국과 프 랑스 국민들의 환송 하에 일본으로 귀환하게 되었다.

제 1 차 세계대전의 승전 결과 연합국들의 합의에 의해 구성된 국제연맹(League of Nations)은 일본의 유럽 방면 전투 참전 조건을 고려하여, 1920년에 개최된 이사회에서 남태평양 방면 도서들에 대한 일본의 위임통치를 결정하 였고, 일본 정부는 1922년에 남양청(南洋廳)을 설치하여,
사이판, 야푸, 팔라우, 트럭, 포나페, 얄토 등의 도서 지역에 민정을 시행하게 되었다(Eguchi 1992). 남양청은 1895년 청일전쟁 승리 이후 일본이 할양받게 된 타이완에 설치한 대만총독부, 그리고 러일전쟁 이후 한반도에 설치한 조선 통감부 및 총독부, 그리고 사할린 50 도 이남에 설치한 화 태청(樺太庁)과 같은, 일종의 식민지 통치기관으로서의 성격을 갖고 있었다.

그런데 국제연맹의 위임을 받아 일본이 통치하게 된 남 양도서, 즉 남태평양 방면의 도서들은 1930년대 이후 일 본이 만주사변을 일으키며 국제연맹을 탈퇴하고, 미국 및 영국과 체결하였던 워싱턴 및 런던 해군군축조약에서도 이탈하면서, 장차 일본이 태평양 방면에서 수행하게 될 대 미 전쟁의 전초기지로서 역할을 부여받게 되었다. 즉 태평 양을 사이에 두고, 1930 년대 이후 일본이 미국과의 해군 력 경쟁을 벌이고, 대미 공격을 염두에 둔 공세적인 전략 계획을 수립하게 되면서, 남태평양 도서들은 대미 해군의 결전 준비를 위한 잠수함 기지로 구상되게 된 것이다 (Japanese Navy Historical Society 1996). 즉 미국과의 전쟁 발생시, 하와이에 중점 배치된 미국 해군 전력이 필리핀 방면 미국 전력과 연결을 도모하면서, 일본을 공략하려 할 때, 남태평양 방면의 일본 잠수함 및 해상전력이 미국 해

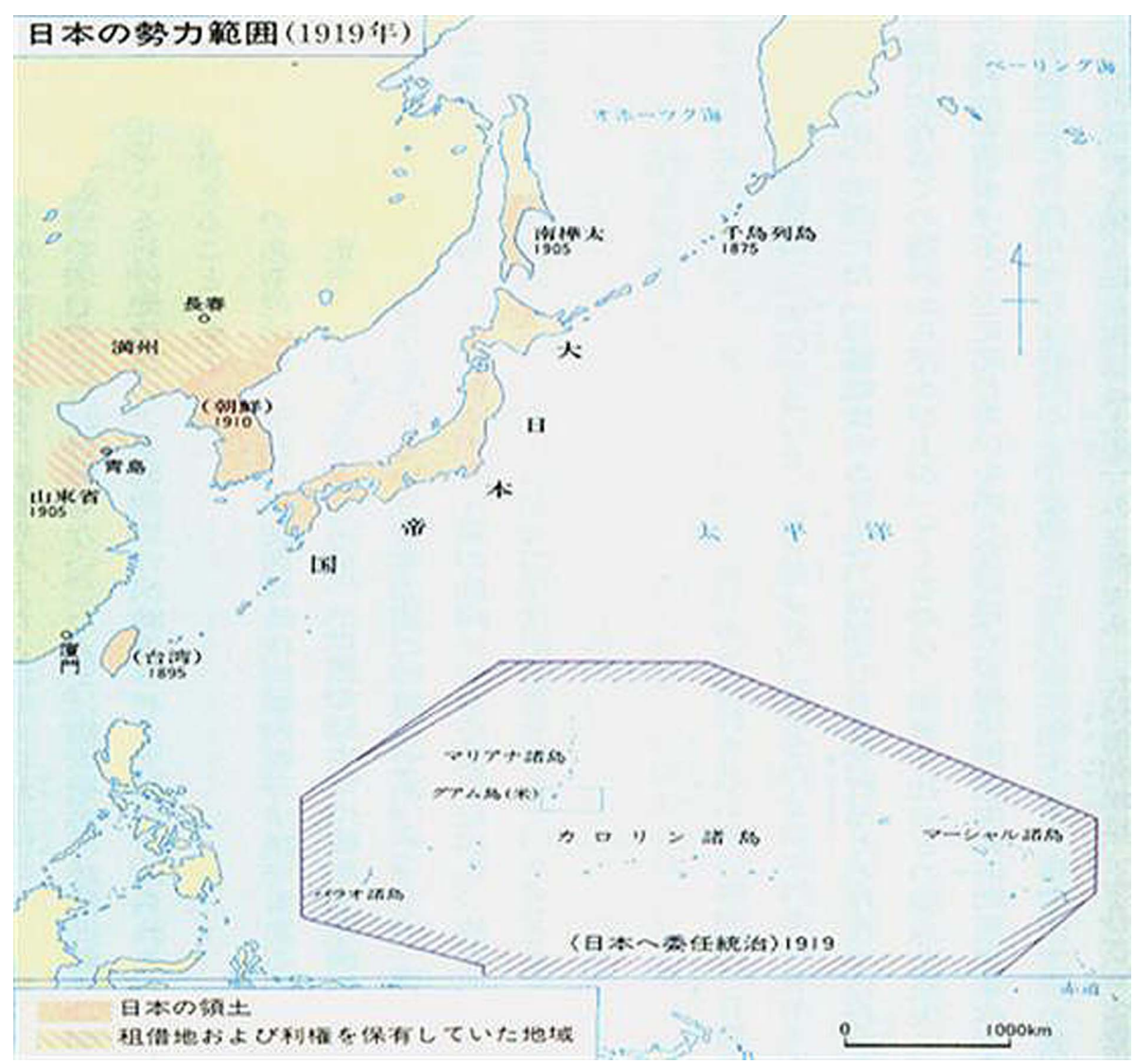

Fig. 2. Japan's Trustship over the South Pacific Islands in 1919 (Arima 1999) 
군 전력을 점진적으로 타격하는 점멸(漸㓕)의 역할을 담당 하게 한다는 것이었다.

이 같은 구상에 따라 일본 해군은 남양도서에 잠수함 부대, 순양함 전대, 그리고 수뢰전대를 배치하고, 1937년 이후에는 남양 위임통치령 지역에 해군 항공기지 건설도 추진하였다(Aizawa 2002). 이 같은 해군 기지 및 해군 항 공기지 건설에 소요되는 노동력을 확보하기 위해 일본 및 식민지 지역에서 노무자들이 대거 동원되었고, 1939년 전 쟁 준비가 본격화되면서부터는 한반도 지역에서도 5,900 여명 이상의 조선인 노무자들이 남양(南洋) 방면으로 도항 하였던 것으로 파악된다(Yamabe 1971).

1937년 중일전쟁이 발발하고, 1940년 이후 일본이 대동 아공영권 건설을 위해 대미 전쟁을 준비하면서, 일본은 남 태평양 도서들을 보다 야심적인 일본의 전략계획에 포함 하려는 정책을 추진하게 된다. 1940년 7월, 제2차 고노에 후미마로(近衞文磨) 내각은, "세계정세의 추이에 기반한 시국처리요강 결정”을 결정하면서, 국방정책 상의 중요성 에 비추어 남양군도를 외교적 조치에 의해 일본 영유로 귀속하는 조치를 취하였다(Aizawa 2002). 즉 남태평양 도 서 지역의 법적 성격을 국제연맹의 위임에 의한 통치지역 이 아니라, 일본의 직접적인 영유권 지역으로 변화시킨 것 이다.

고노에 후미미로 수상은 1918년 이래 영국과 미국 주도 에 의한 국제질서 현상을 비판하면서, 일본의 독자적인 이 익이 반영되는 지역질서 수립을 구상해온 정치인이었다. (Nakanishi 1993) 이러한 그의 구상을 뒷받침하기 위해 수립된 사적 자문기구인 '소화연구회(昭和研究會)'는 1940년에 작성한 강령 초안에서 소위‘동아신질서'건설을 고노에 수상의 대외정책으로 제시하는데, 그 '동아신질서' 의 한 축으로서 남양도서들을 포함한 ‘동아경제권'이 수립 되어야 한다는 내용이 포함되기도 하였다(Sakai 1979).

이상에서 본 바와 같이 남태평양 도서 국가들은 제 1 차 세계대전 이후 일본이 실질적인 통치지역이 되었고, 일 본은 이 도서들을 활용하여 태평양전쟁 전략계획과 소위 '대동아공영권'의 경제질서를 구상하였던 것이다. 이같은 일본의 전쟁계획과 대동아공영권 구상에서 차지하였던 남 태평양 도서 지역의 전략적 중요성 때문에, 태평양전쟁 이 후 승전국으로 부상한 미국은 이들 도서들의 중요성을 각 별히 재평가하지 않을 수 없었다.

\section{태평양 전쟁 이후 미국의 남태평양 도서 정책}

1941년 12월, 일본의 진주만 기습 이후 미국은 일본과 의 태평양전쟁 참전을 결정하게 되었다. 이후 미국은 1942 년의 미드웨이, 과달카날 전투를 거치면서, 1943년의 남태평양 및 북태평양 전투를 치르고, 1944년에는 필리핀 방면에서의 전투를 치르게 되었다. 이같은 전쟁을 치루면
서 미국의 전략가들은 제 1 차 세계대전 이후 국제연맹이 일본에 대해 남태평양 도서들을 위임통치하도록 한 결정 이, 결과적으로 서태평양 해역을 일본의 호수로 만들었고, 이것이 미국의 안전보장에 결정적인 위협을 가하게 되었 다고 인식하게 되었다. 해군 장성들이 주축이 된 미국 전 략가들은 과달카날, 길버트 제도, 보닌 제도, 이오지마 등 에서 일본군과 격전을 치루면서, 제 1 차 세계대전 이후 남 태평양 도서들을 미국이 통제하였더라면, 일본에 의한 진 주만 공격은 없었을 것이라고 한탄하면서, 다시는 제 1 차 세계대전 종전 이후와 같은 전략적 실책을 범하지 않겠다 고 인식하게 되었다(Friedman 2007).

1945년 4월, 상원 위원회에서 증언한 미국 전시함대사 령관 겸 해군 작전사령관(Wartime Commander-in-Chief of the US Fleet and Chief of Naval Operation) 어네스트 킹(Ernest King) 제독은 미국이 전쟁 기간 중 태평양 방면 에서 건설한 기지들은 미국 국력의 골간이며, 전후에도 태 평양상의 전진 도서기지들을 해군이 지속적으로 장악해야 한다고 강조하였다(Friedman 2007). 같은 해 5월 20일, 태 평양상의 연이은 해전들을 승전으로 이끌은 맹장 할제이 (Halsey) 제독도 전후 군사정책을 취급하는 하원 위원회 (the House Select Committee on Post-War Military Policy) 에 제출한 서면 답변을 통해, 미국이 제 1 차 세계대전 시의 실책들을 반성하면서, 전후에도 태평양상의 기지들을 전 적으로 병합하고, 통제해야 한다고 주장하였다(Friedman 2007).

태평양 방면에서의 전쟁이 종료된 1945년 8월 15일 이 후, 미국의 주요 전략가들 사이에서는 전쟁 기간 중 태평 양 방면에서 확보된 미국의 군사기지를 지속적으로 유지 해야 한다는 정책 구상이 보다 강력하게 제기되었다. 1945년 8월 19일, 미국 하원 해군위원회 산하 태평양기지 소위원회는 향후 미국의 태평양상 안보를 위해 마이크로 네시아 지역의 도서, 즉 일본의 남양청 관할하에 있던 도 서들은 물론, 괌, 사이판, 티니안, 그리고 오키나와, 이즈, 오가사와라 등 일본령 도서들을 미국 주권 하에 놓아야 한다는 보고서를 채택하였다(John 1969). 같은 해 9월 5일 과 10 월 1 일, 미 해군과 전쟁성 산하 위원회도 대통령에게 제출한 보고서를 통해 대서양상의 6 개 기지는 물론, 태평 양 상의 알류산, 하와이, 괌, 사이판, 티니안, 이오지마, 오 키나와, 필리핀 등 주요 도서와 기지들을 미국이 계속 장 악해야 한다고 건의하였다(John 1969). 같은 시기, 해군의 전직 사령관이자 제독들인 해리 녹스(Harry Knox), 프레 드릭 해리스(Frederic Harris), 킴멜(Husband Kimmel) 등 은 해군관련 저널에 공동으로 기고한 논문을 통해, 태평양 전쟁의 경험을 통해 볼 때, 태평양 도서들에 해군기지와 항모세력을 유지하는 것이 향후의 미국 전략에도 중요성 을 가질 것이며, 그러한 관점에서 전쟁기간 중 점령한 태 
평양 도서들의 상당수가 잠재적 적대세력을 거부하고, 미 해군의 기동함대 운용의 관점에서 장악되어야 한다고 주 장했다(Friedman 1945).

이같은 미 해군과 의회 전략가들의 정책 구상을 반영하 여 1945년 12월, 모스크바에서 개최된 미영소의 3국 외상 회담에서는, 쿠릴제도와 남부 사할린 지역에 대해서는 소 련의 주장을 수용하고, 태평양상 일본이 위임통치하던 도 서들에 대해서는 미국의 희망에 따라 처분하기로 결정되 었다(John 1969). 모스크바 삼상회의 결정 이후에도 미국 의 전략가들은 태평양 도서에 대한 미국의 전략적 통제 필요성을 지속적으로 주장하였다. 1946년 2월 24일, 미 해군의 작전참모부장 포레스트 셔먼(Forrest B. Sherman) 제독은 상원 해군위원회의 증언을 통해, 태평양 해역에 대 한 전략적 통제를 위해 오키나와, 하와이, 괌-사이판, 마누 스, 필리핀, 아투, 사모아, 팔라우, 트럭 등 태평양상 22개 지역에 소재한 33 개 해군기지와 항공기지를 유지해야 한 다고 주장하였다. 1946년 11월, 유엔 신탁통치위원회의 미국측 대표를 맡고 있던 존 포스터 덜레스도 미국이 태 평양 지역 도서에 대한 사실상의 점유를 계속할 것이라고 밝혔다(John 1969). 태평양 전쟁 이후 미국이 태평양 방면 에 태평양사령부를 유지하고, 미국 서해안인 샌디에이고 에 제3함대를, 그리고 요코스카에 제7함대를 설치하면서, 오키나와 및 괌뿐만 아니라, 남태평양 상의 마리아나 및 캐럴라인 제도를 계속 통제하게 된 것은 이러한 전략적 고려가 반영되었기 때문이다.

\section{21세기 남태평양 해역 전략적 중요성의 재인식}

제 1,2 차 세계대전을 전후하여 일본과 미국 간의 전략적 각축이 된 남태평양 지역은 20 세기 후반부터 다시 국제사 회의 주목을 받게 되었다. 크게 두 가지 이유가 있는 것 같다.

첫째, 1982년 국제해양법협약 체결과, 1994년 그 발효 에 따라 국제해양질서가 전면적으로 재편되면서, 남태평 양 도서 국가들이 광대한 범위의 영해 및 배타적 경제수 역을 갖게 되면서 이 지역의 경제적, 전략적 중요성이 재 부각되었다. 1994년 발효된 유엔해양법조약은 각 조인국 에 대해 기선으로부터의 12해리 범위까지의 영해와 200 해리 범위 내의 배타적 경제수역(Exclusive Economic Zone), 그리고 350 해리 범위 이내에서의 대륙붕을 부여하 고 있다. 이에 따라 남태평양 도서국가들이 비록 면적과 인구가 작지만, 해양영토에 대해서만큼은 광대한 권한을 갖게 된 것이다(Thad et al. 2011). 더욱이 해저광물자원 탐사와 채굴 기술이 발전되면서, 태평양 해역에 메탄하이 드레이트, 코발트, 망간, 레어어스 등 중요 자원이 부존되 어 있다는 것이 밝혀지고 있다. 이러한 해양질서 재편과
해양자원의 중요성 인식에 따라 광대한 배타적 경제수역 을 갖게 된 이들 국가들에 대한 관심이 증폭되게 되었다.

둘째, 남태평양 국가들도 1980년대 중반 이후 일련의 공동체를 조직하며, 국제사회에 자신들의 이익을 주장하 고 목소리를 반영하려는 움직임을 보이기 시작하였다. 1967년 라틴아메리카 국가들이 비핵지대 조약을 체결하 여, 핵보유국들이 자신들을 핵공격하지 않도록 하는 비핵 지대를 최초로 창설하였다. 이를 이어받아 1985년 8월, 남 태평양 13 개 국가들은 남태평양비핵지대를 결성하는 비핵 지대 조약에 서명하였고, 이 조약은 동년 12월에 발효되 었다. 물론 라틴아메리카 비핵지대와 달리, 남태평양 국가 들은 기존 핵보유국들로부터 선제 핵공격 부인을 보장받 지는 못했지만, 이러한 움직임은 이어 1995년 동남아 국 가, 1996년 아프리카 국가, 그리고 2006년 중앙아시아 국 가들 사이에서 연속적으로 비핵지대를 창설하는 기폭제가 되었다.

1995년에는 남태평양 국가들 간에 태평양도서국포럼 (Pacific Island Forum)을 결성하여, 공동의 관심사를 논의 하는 정기적인 협의체가 생겨나기도 하였다. 이같은 남태 평양 국가들의 결속 및 공통적인 메시지 발신은 중동지역 국가들이나 아프리카나, 그리고 중앙아시아 국가들과 마 찬가지로 국제사회에서 일정한 영향력을 갖게 하는 요인 이 되었고, 이러한 움직임에 호응하기라도 하듯, 동아시아 국가들을 포함한 국제사회가 남태평양 국가들과 다양한 형태로 협력을 추구하게끔 하는 요인이 되었다.

\section{4. 동아시아 국가들의 남태평양 도서국가에 대한 외교경쟁}

\section{일본의 남태평양 전략과 외교}

동아시아 국가들 가운데에서 남태평양 지역에 대해 가 장 활발하게 접근하고 있는 국가는 일본이다. 앞에서 살펴 본 것처럼 일본은 1940년대 이전만 해도 마샬, 마이크로 네시아, 팔라우 등 남태평양 지역에 남양청을 설치하여 직 접 영유한 바가 있다. 비록 태평양전쟁 패전 이후 이 지역 에 대한 권리를 상실하였으나, 1970년대 이후 경제적 대 국으로 부상하면서, 다시 이 지역에 경제적, 전략적 관심 을 쏟고 있다. 마이크로네시아 지역 인구의 $20 \%$ 가 일본계 로 추정되고 있는 가운데, 일본은 경제적으로, 외교적으로 이 지역의 가능성을 높게 보고 있다.

우선 경제적으로는 일본인들이 선호하는 참치 어획량의 $80 \%$ 정도가 남태평양 지역에서 생산되고 있으며, 유엔해 양법협약 발효 이후 광대한 배타적 경제수역을 갖게 된 이 지역 국가들의 해저 부존자원도 일본의 관심 대상이 되고 있다. 일본은 2004년부터 일본의 최남단 영토이기도 한 오키노도리시마 주변 해역을 대상으로 해저지질과 지 
하구조에 대한 조사를 실시하였으며, 이를 바탕으로 2009년에 유엔 대륙붕한계위원회에 오키노도리시마 북측 과 남측 해역에 대한 대륙붕 확대를 신청한 바 있다. 이러 한 신청에 대해 2012년 4월, 유엔 대륙붕한계위원회는 오 키노도리시마의 남측 해역에 대해서는 결론을 유보했지 만, 그 북측 해역에 대한 대륙붕 확대에 대해서는 인정한 바 있다.

일본 과학자들은 태평양 해저를 대상으로 해저자원 부 존조사도 활발하게 실시하고 있다. 2011년 7월, 동경대학 연구팀은 하와이와 프랑스령 타이티 해저를 대상으로 레 어어스(희토류) 부존에 대한 연구결과를 발표한 바 있다 (Yasuhiro et al. 2011). 이 결과에 따르면 레어어스의 육지 매장량은 총 1 억1천만톤에 달하는데, 태평양 해저에는 그 800 배에 해당하는 900 억톤이 부존되어 있는 것으로 추정 되었다. 2012년 6월, 동경대학 연구팀은 다시 태평양상의 오가사와라 제도와 일본의 최동단 섬인 미나미도리시마 해역에서 레어어스 600 만톤 이상이 부존된 광상을 다량 발견하였다. 2013년 3월에도 동경대 연구팀과 해양연구개 발기구가 미나미도리시마 해역에서 고농도 레어어스를 발 견하였다고 발표하였다. 일본은 연간 3 만톤 정도의 레어 어스를 주로 중국에서 수입해서 사용하고 있는데, 이같은 태평양 지역 해저 부존자원의 개발은 전략자원인 레어어 스의 대중국 의존도를 줄이는 효과적인 방편으로도 기대 되고 있는 것이 실정이고, 이러한 측면에서 광대한 배타적 경제수역을 가진 남태평양 국가들에 대해 일본이 적극적 으로 접근하고 있는 것으로 보여진다.

일본은 외교적으로도 남태평양 국가들이 필요하다. 일 본은 2000년대 이후 유엔 안전보장이사회 상임이사국 진 출을 시도해 오고 있는데, 14 개 국가 가운데 12 개 국가가 유엔에 가입해 있는 남태평양 도서 국가들의 영향력은 무 시못할 요인인 것이다. 그렇다면 일본은 어떻게 남태평양 국가들에 접근하고 있는 것일까?

일본은 1997년 이후 3년을 주기로 남태평양 국가들과 일본-태평양 도서국 정상회의를 개최해 오고 있다(박 2012). 예컨대 2006년에 고이즈미 수상의 주관 하에 오 키나와에서 개최된 제4회 일본-태평양도서 정상회의에는 호주, 뉴질랜드, 파푸아뉴기니, 피지, 통가, 솔로몬, 팔라 우 등 16 개국이 참가하였다. 이 회의에서 일본은 향후 3 년간 450 억 엔의 경제 원조를 이들 국가들에 대해 실시 하기로 합의한 바 있다. 이같은 액수는 전회 정상회의에 서 지출을 약속한 100 억엔 규모에 비해 대폭 증액된 것 이었다.

2009년 5월, 제 5회 일본-태평양도서국 정상회의는 역시 16 개국이 참가한 가운데 홋카이도에서 개최되었다. 이 회 의에서는 일본과 태평양 도서국가들이 상호 태평양 환경 공동체를 창설한다는 합의가 발표되었고, 일본은 이들 국
가들에 대해 향후 3 년간 환경대책과 인재육성을 목적으로 총 500 억엔 규모의 경제지원을 할 것을 표명하였다.

2012년 5월 25일에 오키나와에서 개최된 제6회 일본-태 평양도서국 정상회의는 일본 민주당 정권이 주관한 회의 였다. 즉 자민당에서 민주당으로 정권이 교대되어도 태평 양도서국가들과의 협력관계를 상징하는 이 회의는 기본적 으로 유지된 것이다. 이 회의에서는 일본측 요청으로 미국 이 최초로 참가하였으며, 회의 종료시에 발표된 공동성명 에는 참가국들 간에 해양안전보장을 도모한다는 표현이 처음으로 포함되었다. 당시 중국측과 센카쿠를 둘러싸고 대립하던 일본이 미국도 참가시키고, 해양안보의 표현도 공동선언문에 포함시키는 형태로 대중 전략의 일환으로 이 협의체를 활용한 것이다.

제6회 일본-태평양 도서국 정상회의에서 나타났듯이 일 본은 남태평양 지역에 대한 안보적 관여정책도 신중하게 추진하고 있다. 2010년 3월에는 일본 해상보안청, 외무성 등이 미국 및 호주의 관계기관과 협력하여, 팔라우, 마이 크로네시아, 마샬 제도 등 3 개국에 연안경비대 창설을 지 원하기 위한 준비회의를 개최하여, 2011년 4월, 이 지역에 최초로 연안경비대가 창설되는데 도움을 주었다. 2012년 2월에는 파푸아뉴기니와 통가에 대해서도 도로보수나 건 설기술 제공 등 사회인프라 구축을 위해 일본 자위대가 지원 가능한지의 여부를 타진하기도 하였다. 후술하듯이 중국도 이 지역에 대한 경제적, 안보적 진출을 적극 추진 하고 있는 추세에 비추어 볼 때, 일본도 향후 남태평양 도 서 국가들에 대한 경제적, 안보적, 사회문화적 관여를 더 욱 확대해 갈 것으로 전망된다.

\section{중국의 남태평양 외교}

중국도 1980 년대 이후 경제대국으로 부상하면서, 해양 과 관련된 국가이익 개념을 개발하고, 이를 수행하기 위한 적극적 해양전략을 모색하고 있다. 1982년 중국 해군사령 원이자 중앙군사위 부주석을 겸임하던 류화칭(劉華淸) 제 독은 제 1 도련과 제 2 도련(島連) 개념을 발표하면서, 중국이 2000년까지는 타이완-오키나와-필리핀을 잇는 라인까지 제해권을 확립하고, 2020 년까지는 오가사와라-괌-인도네 시아를 잇는 제 2 도련의 해역까지 해군 활동을 확대할 것 이라고 밝힌 바 있다. 또한 유엔대륙붕협약을 비준하면서, 자신들의 배타적 경제수역내 권리를 주장하고, 그 외곽의 해역에 대해서도 대륙붕을 확장하기 위해 유엔대륙붕 한 계위원회에 자신들의 주장을 제출하고 있다. 최근에는 인 도양 해역에까지 해군 활동을 확대하려는 움직임도 노정 하고 있다(Che 2012).

이러한 중국의 해양전략 추진에 있어 남태평양 도서국 가들은 중요한 위상을 갖는다. 우선 중국이 설정한 제2도 련선, 즉 이즈 제도-오가사와라 제도-괌-인도네시아를 잇 
는 라인이 마이크로네시아와 팔라우를 경유하게 되어 있 어, 태평양 도서국가들 자체가 중국의 전략적 이익과 직결 되게 되어 있다. 더욱이 태평양도서국가에 대한 일본의 적 극외교는, 센가쿠(중국명 釣魚島) 영유권 문제를 둘러싸고 일본과 대립관계를 노정하고 있는 중국으로서도 방관할 수 없는 문제가 되고 있다.

이러한 이유 때문에 중국도 뒤늦게나마 이 지역에 대 한 외교노력을 가속화하고 있다. 2006년 4월, 중국의 원 자바오 수상은 피지에서 남태평양 8개 도서국가를 초청 하여 중국-태평양도서국가 경제개발협력 포럼을 최초로 개최하였다. 이 회의에서 원자바오 수상은 2006-2009년 간 중국이 전체 6 억 달러 규모의 경제지원을 한다고 표 명하였다. 2013년 가을에는 제2차 중국-태평양 도서국가 정상회의 개최가 예정되어 있다. 정부 차원의 경제협력 과 더불어 중국 민간기업들도 남태평양 도서국가에 대한 투자를 늘리고 있다. 중국 부동산 회사들은 2012년에 마 이크로네시아 지방정부와 투자협정을 체결하면서 리조트 단지 등을 건설하려는 계획을 추진하고 있고, 니켈 자원 이 풍부한 파푸아뉴기니에 대해서도 중국의 지원이 이루 어지고 있다.

중국은 이 지역에 대한 경제협력 관계에 더해 안보협력 도 추진하고 있다. 매년 각국의 고급 장교들을 초빙하여 국제안보협력 교육프로그램을 활발하게 진행하고 있는 중 국 국방대학은 매년 중국-태평양도서국가 안보협력회의를 병행하여 개최하고 있다.

남태평양 도서 국가들에 대한 중국의 경제적, 전략적 협력은 시진핑 체제 등장 이후 더욱 가속화될 전망이다. 시진핑 체제의 출범을 정식으로 공식화한 제 18 차 공산당 대회에서는 국가전략의 일환으로 해양강국(maritime power) 건설이 표방되었다(Geng 2013). 당대회 이후 중국 은 국가기구 개혁을 추진하고 있는데, 기존의 국가해양국 권한을 강화하고, 중앙정부 조직으로 국가해양위원회를 신설할 것으로 전망되고 있다. 수상으로 선출된 리커창(李 克强)은 중국의 심해탐사선 활동 및 남극기지 건설 활동 등을 평가하면서, 향후 중국이 해양이익을 보호하기 위한 법률을 정비하고, 나아가 해양분야의 국제협력을 강화하 겠다는 방침도 표명하고 있다(Wang 2013).

이같은 중국 신지도부의 해양 정책방향은 단기적으로는 일본 등과의 영유권 분쟁 대응, 중장기적으로는 미국과의 전략적 관계 재정립 및 해외 자원 확보 등의 전략과 결부 된 것으로 보인다. 이같은 해양 전략의 연장선상에서 중국 은 남태평양 도서 국가들과의 다양한 해양협력도 확대할 것으로 전망된다.

\section{한국의 남태평양 도서국가 외교}

일본과 중국에 비해 한국의 남태평양 도서국가들에 대
한 외교는 미흡한 실정이다. 한국은 오래 전부터 남태평양 지역에서 활발한 원양어업을 실시하고 있었으나, 이 지역 을 경제적, 외교적으로 중시하는 정책은 거의 없었다고 해 도 과언이 아니다. 한국 외교는 미일중러 등 동아시아 지 역에 중점을 두어왔기 때문에, 여타 지역 국가에 대한 외 교도 마찬가지로, 남태평양 도서 국가에 대한 외교가 소홀 했던 것이 사실이다.

다만 최근에 한국이 녹색성장이나 글로벌 지원사업에 관심을 보이면서, 남태평양 도서 국가들에 대한 정책적 관 심이 기울여지고 있는 것 같다. 이명박 정부가 등장한 2008년부터 한국은 기후변화 파트너십 사업을 동북아, 동 남아, 중앙아시아, 남아시아 국가들을 대상으로 실시해 오 고 있는데, 여기에 더해 남태평양 도서국가들인 피지, 마 샬군도, 마이크로네시아, 키리바시, 투발루, 나우루, 바누 아투, 솔로몬제도, 사모아, 통가, 니우에, 쿡 제도, 팔라우 등을 포함시킨 바 있다(김 2012).

그리고 2011년 5월 31일, 한국은 일본 및 중국의 외교 에서 영향받아, 외교장관급 인사들을 대상으로 하여 최초 의 한국-태평양 도서국가 회의를 개최하였다. 이 회의에는 파푸아 뉴기니, 피지, 마샬군도, 쿡 제도, 솔로몬 제도, 투 발루, 바누아투, 통가, 팔라우, 나우루, 니우에, 키리바시, 마이크로네시아, 사모아 등 14 개국 장관급 인사들이 참가 하였다. 그리고 2012년도에는 이 가운데 미수교국이었던 쿡 제도와 국교를 수립한 것이다. 비록 뒤늦었지만, 한국 의 남태평양 국가들에 대한 외교는 지금부터가 시작인 것 이다.

\section{5. 향후 한국의 전략적 대응방안}

남태평양 국가들은 면적이나 인구 규모가 다른 국가들 에 비해서 작다. 경제적으로도, 외교적으로도 국제사회에 서 영향력을 발휘하는 국가들이 아니다. 그런 국가들에 대 해서 1,2 차 세계대전 전후해서는 미국과 일본이 각각 각 축전을 벌였고, 1990 년대 이후에는 일본과 중국이 마치 구애경쟁이라도 하듯, 경쟁적으로 개별적인 정상회담을 갖고, 경제지원을 아끼지 않아왔다.

이러한 강대국들이 존재 자체가 미미한 남태평양 국가 들에 대해서 '쟁탈전'이라도 하듯, 경제적, 외교적 접근을 해온 것은 크게 보아, 이들 지역이 가진 경제적, 외교적 잠 재력을 날카롭게 인식했기 때문이라고 보인다. 1982년 유 엔해양법협약이 체결된 이후 국가들은 영토와 인구의 크 기에 못지않게 배타적 경제수역과 대륙붕의 크기가 국제 적 영향력을 갖는 시대가 되었다. 그 배타적 경제수역과 대륙붕의 해저에 부존된 해저자원은, 아직 개발여부도 불 투명하지만, 미래의 자원 대국 여하를 가르는 중요한 요소 의 하나로 부상하고 있다. 해양질서에 잠재된 이러한 요소 
들에 주목한다면, 태평양 도서 국가들은 결코 미미한 존재 가 아닌 것이다.

또한 1985년에 남태평양 비핵지대를 결성하고, 1995년 에는 태평양도서포럼을 창설한 이들 국가들은 유엔을 비 롯한 국제무대에서 무시할 수 없는 세력으로 등장하고 있 다. 물론 50 여개 국가들로 구성된 아프리카 연합이나, 중 동 및 라틴아메리카 국가들에 비해서 수적 규모는 작지 만, 국제무대에서 14표는 무시할 수 없는 세력이다. 따라 서 국제질서상 영향력을 강화하려고 애쓰는 국가들에게 남태평양 국가들은 결코 미약한 존재들이 아니다.

일본은 이러한 남태평양 국가들의 경제적, 외교적 잠재 력에 주목하고 1990년대 중반부터 일본-태평양 도서국가 정상회의체를 가동시켜 지속적으로 경제지원을 실시하는 등 협력관계를 발전시키고 있다. 경제대국으로 부상한 중 국도 뒤늦긴 하지만, 2006년부터 중국-태평양도서포럼 정 상회의를 가동시키고, 동시에 중국 국방대를 중심으로 한 안보협력회의도 개최하면서, 경제적, 안보적 협력을 심화 시키고 있다. 이들 주변국가들이 남태평양 국가들과 경제 적, 외교적 협력관계를 발전시키는 것은 비단 경제적으로 여유가 있어서 만은 아니다. 미래에 예상되는 경제적 필 요, 혹은 외교적 필요를 내다보며, 현 시점에서 적절한 포 석을 짜는 것이라고 판단된다.

한국은 일본이나 중국보다 뒤늦게 남태평양 국가들과의 외교적, 기후변화적 차원에서의 협력관계 구축에 나서고 있다. 한국은 후발 주자임이 분명하다. 그런데 후발주자이 기 때문에, 한국은 선발주자인 일본과 중국과는 다른 접근 을 할 필요가 있다. 단순히 선발주자들이 한다고 해서 남 태평양 도서국가들과 외교적 협의체를 갖는다면, 상대국 들에게 좋은 인상을 줄 수가 없다. 그런데 지금의 한국 외 교에는 그러한 전략이 결핍되어 있는 것으로 보인다. 일본 과 중국 등의 선발 주자들이 착안하지 못하는 협력 방안, 그러면서 당사국들이 필요로 하고, 우리도 도움이 되는 그 러한 협력방안을 강구해야 한다. 그 길은 과연 무엇일까? 이 길을 찾아내기 위해서 우리는 남태평양 도서국가들에 대한 지역연구를 병행시키면서, 이들 지역에 대한 외교적, 경제적 접근을 추진하는 것이 바람직할 것이다.

\section{사 사}

본 연구는 한국해양과학기술원의 '적도태평양 연구인프 라 구축사업(PE98962)'의 지원에 의해 수행되었습니다.

\section{참고문헌}

김양희 (2012) 한일 환경협력. In: 2012년도 한일신시대공동
연구위원회 워크샵 자료집, 2012년 11월 25일

박영준 (2012) 21세기 일본의 해양질서 구상과 해양정책. 외 교 안보연구 8(1):227-251

Aizawa J (2002) Choice of the Navy: Reconsidering the Path to the Pearl Harbor. Chuokoron Sinsha Publishing Company, Tokyo, 246 p (In Japanese)

Arima M (1999) Imperial Japan amidst the Internationalization, 1905-1924. Chuokoronsha Publishing Company, Tokyo, 352 p (In Japanese)

Che H (2012) Chinese navy to actively maintain peace and stability of Indian Ocean. http://english.people.com.cn/ 90786/8060266.html Accessed 7 Dec 2013

Eguchi K (1992) Imperial Japan's rule over East Asia. In: Ooe S, Mitani T, Kobayashi H, Wakabayashi M, Asada K, Koto K, Takasaki S, Kawamura M (eds) Modern Japan and Colonies. Iwanami Shoten Publishing Company, Tokyo, pp 317 (In Japanese)

Friedman HM (2007) Governing the American Lake: The U.S. Defense and Administration of the Pacific, 19451947. Michigan State University Press, 276 p

Geng X (2013) Marine affairs ministry needed for China to navigate maritime interests. http://www.globaltimes.cn/ content/754325.shtml Accessed 9 Dec 2013

Hirama Y (1998) The First World War and Japanese Navy. Keio University Press, Tokyo, 355 p (In Japanese)

Japanese Navy Historical Society (1996) Naval History of Japan. Vol.3. Japanese Navy Historical Society, 240 p (In Japanese)

John DW (1971) Occupied Japan and the American Lake, 1945-1950. In: Edward F, Mark S (eds) America's Asia: Dissenting Essays on Asian-American Relations. Random House, New York, pp 146-206

Knox HG, Harris FR, Kimmel HE (1945) Naval bases : past and future. In: Naval Institute Proceedings of October 1945. U.S. Naval Institute, pp 10

Nakanishi H (1993) Responding to Universalism - Background of Konoe Fumimaro's Article on Anti-Anglo-American Pacifism. Kyoto Law Rev 132:225-258 (In Japanese)

Oguma E (1996) Origins of the Myth of Unitary Nation. Sinyosha Publishing Company, 450 p (In Japanese)

Sakai S (1979) Showa Research Association: A Path of an Intellectual Group. TBS-BRITANICA, Tokyo, 388 p (In Japanese)

Thad W, Richard LA, John JH (2011) Odd man out at sea. http://www.nytimes.com/2011/04/25/opinion/25allen. html?_r $=0$ Accessed 9 Dec 2013

Wang Y (2013) Li Keqiang urges marine interests safeguarding. http://news.xinhuanet.com/english/china/2013-02/07/c 
132158424.htm Accessed 8 Dec 2013

Yasuhiro K, Koichiro F, Kentaro N, Yutaro T, Kenichi K, Junichiro O, Ryuichi T, Takuya N, Hikaru I (2011) Deep-sea mud in the Pacific Ocean as a potential resource for rareearth elements. Nat Geosci 4:535-539

Yamabe K (1971) Chosen under the Japanese rule. Iwanami
Shinsho Publishing Company, Tokyo, 227 p (In Japanese)

Received Aug. 29, 2013

Revised Nov. 7, 2013

Accepted Nov. 15, 2013 